The pathogenesis of isolated organ vasculitis is unknown, as is why only one organ may be affected. Localised infection has been suggested in limited Wegener's granulomatosis. ANCAs are now being found to have a pathogenetic role in some systemic vasculitides but the absence of ANCAs in most cases of classic polyarteritis nodosa suggests that cell mediated immunity may also be important.

To treat this patient with potentially toxic immunosuppressive therapy with the added risk of sterility, despite the lack of clinical and objective laboratory evidence of systemic disease, was a difficult clinical decision. In view of the high relapse rate associated with polyarteritis nodosa, long term follow up is essential. The absence of serological markers of disease activity, however, may make monitoring of any future relapse difficult.

We are grateful to Mr DMA Wallace and Dr D Adu for permission to report on this patient.
1 Huisman TK, Collins WT Jr, Voulgaris GR. Polyarteritis nodosa masquerading as a primary testicular neoplasm; a case report and review of the literature. F Urol 1990; 144:1236-8.

2 Belville WD, Insalaco SJ, Dresner ML, Buck AS. Benign testis tumours. $\mathcal{F}$ Urol 1982;128:1 198-200.

3 Lee LM, Moloney PJ, Wong HCG, Magil AB, McLoughlin MG. Testicular pain: an unusual presentation of polyarteritis nodosa. F Urol 1983;129:1243-4.

4 Gondos B, Wong TW. Non-neoplastic diseases of the testis and epididymis: In: Murphy W, ed. Urological testis and epididymis: In: Murphy W, ed. 24-313.

5 Shurbaii MS, Epstein JI. Testicular vasculitis: implications for systemic disease. Hum Pathol 1988;19:186-9.

6 Womack C, Ansell ID. Isolated arteritis of the epididymis. f Clin Pathol 1985;38:797-800.

7 Borrie P. Cutaneous polyarteritis nodosa. $\mathrm{Br} F$ Dermatol 1972;87:87-95.

8 Carrington CB, Liebow AA. Limited forms of angiitis and granulomatosis of Wegener's type. Am F Med 1966;41: 497-527.

9 Gordon M, Luqmani RA, Adu D, Greaves I, Richards N, Michael J, et al. Relapses in patients with a systemic vasMichael J, et al. Relapses in patients
culitis. $Q \mathcal{M}$ Med 1993;86:779-89.

10 Adu D, Luqmani RA, Bacon PA. Polyarteritis, Wegener's granulomatosis and Churg-Strauss syndrome. In Maddison PJ, Isenberg DA, Woo P, Glass DN, eds. Oxford Textbook of Rheumatology. Oxford: Oxford University Press, 1993;846-59.

11 Hayward I, Trambert MA, Mattrey RM, Salzstein SL, Demby AM. MR imaging of vasculitis of the testis. f Comput Assist Tomogr 1991;15:502-4.

\title{
Lymphocytic gastritis, gastric adenocarcinoma, and primary gastric lymphoma
}

\author{
A P Griffiths, J Wyatt, A S Jack, M F Dixon
}

Department of

Histopathology, Neath

General Hospital,

Neath,

West Glamorgan

SA11 2LQ

A P Griffiths

Department of

Histopathology, St

James's University

Hospital, Leeds

J Wyatt

Academic Unit of Pathological Sciences, University of Leeds

A S Jack

M F Dixon

Correspondence to:

Dr A P Griffiths

Accepted for publication 10 May 1994

\begin{abstract}
A series of primary gastric lymphomas and adenocarcinomas was reviewed to assess the prevalence of lymphocytic gastritis in these conditions. Lymphocytic gastritis was more prevalent in patients with gastric adenocarcinoma (16 of 130 cases; $12 \cdot 3 \%$ ) and primary gastric lymphoma (six of 45 cases; 13.7\%) than in unselected patients undergoing endoscopy $(0 \cdot 83-2 \cdot 5 \%)$. This suggests that these two disparate gastric tumours may share an immunological dysfunction or a common pathogenesis, and this is of interest given that Helicobacter pylori is thought to have a role in the evolution of gastric adenocarcinoma and lymphoma.
\end{abstract}

(F Clin Pathol 1994;47:1123-1124)

Intraepithelial lymphocytosis is a well recognised component of gluten sensitive enteropathy and the role of these $T$ lymphocytes in the pathogenesis of coeliac disease has been the focus of much attention. Dramatic intraepithelial lymphocytosis (lymphocytic gastritis) has also been described in the gastric mucosa. ${ }^{1}$ This condition is sometimes suspected clinically because of the presence of varioliform gastritis on endoscopy. ${ }^{1}$ Serological evidence of Helicobacter pylori infection is present in most, but not all, of these cases, ${ }^{2}$ but the precise link between $H$ pylori and lymphocytic gastritis is unknown. A hypertrophic form has been recognised and distinguished from Menetrier's disease. ${ }^{3}$ Lymphocytic gastritis also occurs in a substantial proportion of patients with coeliac disease. ${ }^{4}$ The disorder affects the whole stomach ${ }^{5}$ and occurs with an incidence of between 0.83 and $2.5 \%$ in unselected patients undergoing endoscopy, ${ }^{6}$ and of $4.5 \%$ in those with chronic gastritis. ${ }^{2}$

Concurrent lymphocytic gastritis and primary gastric tumours in resection specimens prompted us to review a series of primary gastric lymphomas and adenocarcinomas to assess the prevalence of lymphocytic gastritis in these conditions.

\section{Methods}

Specimens were retrieved from the archives of Leeds General Infirmary and St James's University Hospital, Leeds, and from the Yorkshire Regional Lymphoma Panel. A total of 52 gastric lymphomas were examined, 45 of which had features associated with primary gastric mucosa associated lymphoid tissue (MALT) lymphoma. ${ }^{7}$ We also examined 130 cases of primary gastric adenocarcinoma. 


\section{Results}

Lymphocytic gastritis was present in six of the $45(13 \cdot 7 \%)$ MALT lymphoma cases; lymphocytic gastritis was not found in the non-MALT lymphoma cases. Of the 130 cases of adenocarcinoma, $16(12 \cdot 3 \%)$ had concomitant lymphocytic gastritis. The prevalence of lymphocytic gastritis was the same in cases of intestinal type and diffuse carcinoma.

\section{Discussion}

The prevalence of lymphocytic gastritis in both primary gastric MALT lymphoma and gastric adenocarcinoma is clearly much greater than that seen in non-ulcer dyspepsia ${ }^{6}$ and chronic active gastritis. ${ }^{2}$ This suggests that lymphocytic gastritis may be associated with an increased risk of developing lymphoma or carcinoma. It is particularly intriguing that the prevalence of lymphocytic gastritis is similar in both gastric lymphoma and adenocarcinoma given the current hypotheses linking both tumours with $H$ pylori infection.

$H$ pylori infection was not determined in this retrospective series because gastrectomy specimens are unsuitable for the histological detection of $H$ pylori; this is attributed to reduced sensitivity following suboptimal fixation. ${ }^{8}$ Furthermore, most patients with lymphocytic gastritis are $H$ pylori positive despite the absence of the organism on histology. ${ }^{2}$

Most patients with gastric carcinoma also have chronic gastritis. In a previous study from Leeds some form of chronic gastritis was present in 50 of 52 gastric biopsy specimens taken from sites other than the tumour in patients with gastric adenocarcinoma; however, $H$ pylori was detected in only 21 $(42 \%)$ of these. ${ }^{9}$ This observation agrees with the hypothesis that $H$ pylori gastritis is important in the early stages of carcinogenesis, although the organism may no longer be detectable when the tumour is clinically apparent. In 19 patients with gastric adeno- carcinoma studied using mucosal immunology there was evidence of current or previous $H$ pylori infection in $18 .{ }^{10}$

That lymphocytic gastritis is not a direct precursor or premalignant phase of primary gastric lymphoma is evident from the fact that the neoplastic lymphocytes in the latter condition are B cells, whilst the intraepithelial lymphocytes in the former are CD8 positive $\mathrm{T}$ cells. However, cytokines secreted by $\mathrm{T}$ cells in $H$ pylori gastritis may promote $\mathrm{B}$ cell proliferation. ${ }^{11}$

Further research on the relation between lymphocytic gastritis, gastric MALT lymphoma, gastric adenocarcinoma, and $H$ pylori could yield important clues to the cause and pathogenesis of these conditions.

1 Haot J, Delos M, Wallez L, Hardy N, Lenzen B, JouretMourin A. Intra-epithelial lymphocytes in inflammatory gastric pathology. Acta Endosc 1986;16:61-7.

2 Dixon MF, Wyatt II, Burke DA, Rathbone BJ Lymphocytic gastritis-relationship to Campylobacter pylori infection. $\mathcal{F}$ Pathol 1988;154:125-32.

3 Wolfsen HC, Carpenter HA, Talley NJ. Menetrier's disease: a form of hypertrophic gastropathy or gastritis? Gastroenterology 1993;104:1310-9.

4 Wolber R, Owen D, Del Buono L, Appelman H, Freeman $H$. Lymphocytic gastritis in patients with celiac sprue or spruelike intestinal disease. Gastroenterology 1990;98. 310-5.

5 Rubio CA, Befritz R, Eriksson B, Christensson B, Duvander A, Larsson B. The topographic distribution of lymphocytic gastritis in gastrectomy specimens. Acto of lymphocytic gastritis in gastrectomy specim
Pathol Microbiol Immunol Scand 1991;99:815-9.

6 Jaskiewicz K, Price SK, Zak J, Louwrens HD. Lymphocytic gastritis in non ulcer dyspepsia. Dig Dis Sci 1991;36:1079-83.

7 Wright DH, Isaacson PG. Gut-associated lymphoid tumours. In: Whitehead $\mathrm{R}$, ed. Gastrointestinal and oesophageal pathology. Edinburgh: Churchill Livingstone, 1989:643-61.

8 Wyatt JI, Gray SF. Detection of Helicobacter pylori by histology. In: Rathbone BJ, Heatley RV, eds. Helicobacter pylori and gastroduodenal disease. 2nd edn Oxford: Blackwell Scientific Publications, 1992:51-7.

9 Rathbone BJ, Wyatt JI. Campylobacter pylori and precancerous conditions. In: Reed PI, Hill MJ, eds. Gastric cerous conditions. In: Reed PI, Hill MJ, eds. Gastric
carcinogenesis. Proceedings of the 6th Annual Symposium of the European Organisation for Cooperation in Cancer Prevention Studies. Amsterdam Excerpta Medica, 1988:137-44.

10 Crabtree JE, Wyatt JI, Sobala GM, Miller G, Tompkins DS, Primrose JN, et al. Systemic and mucosal humoral responses to Helicobacter pylori in gastric cancer. Gut 1993;34:1339-43.

11 Hussell $T$, Isaacson $P$, Crabtree JE Spencer J. The response of cells from low grade B cell gastric lymphomas of mucosa associated lymphoid tissue to phomas of mucosa associated lymphoid 